\begin{tabular}{|c|c|c|}
\hline BIODIK & $\begin{array}{c}\text { BIODIK: Jurnal IImiah Pendidikan Biologi } \\
\text { ISSN 2580-0922 (online), ISSN 2460-2612 (print) } \\
\text { Volume 6, Nomor 04, Tahun 2020, Hal. } 492-506 \\
\text { Available online at: } \\
\text { https://online-journal.unja.ac.id/biodik }\end{array}$ & BIODIK \\
\hline
\end{tabular}

Research Article

open access

\title{
Pengembangan Booklet Keanekaragaman Kupu-Kupu Di Kabupaten Kerinci dan Sekitarnya Sebagai Sumber Belajar Pada Materi Animalia Kelas X SMA
}

\section{(Booklet Development of Butterfly Biodiversity in Kerinci Regency and its Surroundings as Learning Resource in Chapter Animalia Class X Senior High School)}

\author{
Bestia Dewi *, Afreni Hamidah, Tedjo Sukmono \\ Universitas Jambi \\ JI. Lintas Jambi-Ma.Bulian KM 15 Mendalo Indah-Jambi-Indonesia \\ *Corresponding Author: bestia.dewi92@gmail.com
}

\begin{tabular}{|c|c|}
\hline Informasi Artikel & ABSTRACT \\
\hline $\begin{array}{l}\text { Submit: } 16-07-2020 \\
\text { Diterima: } 09-10-2020 \\
\text { Dipublikasikan: } 18-12-2020\end{array}$ & $\begin{array}{l}\text { Learning resources play an important role in the learning process. The benefits of } \\
\text { learning resources are as a support for learning activities, adding and expanding the } \\
\text { presentation of material that might not be summarized in the textbooks. Most of the } \\
\text { learning resources used by students today are still in unattractive form. The available } \\
\text { learning resources also do not explain examples of animals that can be found around } \\
\text { (contextual). Also, the difficulty of getting learning resources for Animalia materials } \\
\text { that are per the learning objectives is an obstacle that causes the unavailability of } \\
\text { Animalia learning resources. Therefore, innovation is needed to develop a learning } \\
\text { resource that is suitable for the learning objectives. This development was done due } \\
\text { to a lack of learning resources with the elaboration of animals found in surrounding } \\
\text { (Contextual). This development study aimed to design a booklet of butterfly } \\
\text { biodiversity in Kerinci regency and its surroundings as a learning resource in Chapter } \\
\text { Animalia Class X Senior High School, to determine teachers' and students' } \\
\text { responses. The development model used in this study was the ADDIE model. ADDIE } \\
\text { model consists of } 5 \text { steps: Analysis, Design, Development, Implementation, and } \\
\text { Evaluation. The booklet was validated by media experts and material experts in the } \\
\text { very appropriate category. The response from the teachers to the booklet was good. } \\
\text { The response from the students to the booklet in a small group trial and large group } \\
\text { trials was very good. Based on the results of the study it can be concluded that } \\
\text { booklet of butterfly biodiversity in Kerinci regency and its surroundings is appropriate } \\
\text { for use by high school grade X students as learning resources for Animalia chapter. } \\
\text { Keywords: : Booklet, butterfly, Animalia, ADDIE }\end{array}$ \\
\hline Penerbit & ABSTRAK \\
\hline $\begin{array}{l}\text { Program Studi Pendidikan } \\
\text { Biologi, Fakultas Keguruan dan } \\
\text { Ilmu Pendidikan, Universitas } \\
\text { Jambi-Indonesia }\end{array}$ & $\begin{array}{l}\text { Sumber belajar berperan penting dalam kegiatan pembelajaran. Beberapa manfaat } \\
\text { sumber belajar yaitu sebagai penunjang kegiatan pembelajaran, menambah dan } \\
\text { memperluas sajian materi yang mungkin tidak terangkum didalam buku paket. } \\
\text { Sebagian besar sumber belajar yang digunakan siswa saat ini masih dalam bentuk } \\
\text { yang kurang menarik. Sumber belajar yang tersedia juga tidak menjelaskan contoh- } \\
\text { contoh hewan yang dapat ditemui disekitar (kontekstual). Selain itu, sulitnya } \\
\text { mendapatkan sumber belajar materi Animalia yang sesuai dengan tujuan } \\
\text { pembelajaran menjadi kendala yang menyebabkan tidak tersedianya sumber belajar } \\
\text { materi Animalia di sekolah. Sehingga, diperlukan suatu inovasi untuk } \\
\text { mengembangkan suatu sumber belajar yang sesuai dengan tujuan pembelajaran. } \\
\text { Tujuan dari penelitian pengembangan ini adalah untuk menghasilkan booklet } \\
\text { keanekaragaman kupu-kupu di Kabupaten Kerinci dan sekitarnya sebagai sumber } \\
\text { belajar pada materi Animalia kelas X SMA, mengetahui respon guru dan respon } \\
\text { siswa terhadap booklet yang dikembangkan. Model pengembangan yang digunakan } \\
\text { dalam penelitian ini adalah model ADDIE. Model ADDIE terdiri dari } 5 \text { tahapan yaitu } \\
\text { Analysis, Design, Development, Implementation dan Evaluation. Booklet divalidasi }\end{array}$ \\
\hline
\end{tabular}


oleh ahli media dan ahli materi dengan perolehan hasil sangat layak. Respon guru terhadap booklet pada kategori baik. Respon siswa terhadap booklet pada ujicoba kelompok kecil dan kelompok besar pada kategori sangat baik. Berdasarkan hasil penelitian dapat disimpulkan bahwa booklet keanekaragaman kupu-kupu di Kabupaten Kerinci dan sekitarnya layak digunakan siswa kelas X SMA sebagai sumber belajar materi Animalia.

Katakunci: Booklet, kupu-kupu, Animalia, ADDIE

This BIODIK : Jurnal IImiah Pendidikan Biologi is licensed under a CC BY-NC-SA (Creative Commons Attribution-ShareAlike 4.0 International License)

\section{PENDAHULUAN}

Sumber belajar merupakan segala sesuatu yang dapat membantu untuk belajar (Karwono \& Mularsih, 2018). Menurut Daryanto (2016) sumber belajar adalah segala sesuatu yang ada di sekitar lingkungan belajar, baik yang dirancang maupun yang langsung dapat dimanfaatkan dan digunakan untuk mengoptimalisasi proses dan hasil pembelajaran. Manfaat sumber belajar bagi pendidik yaitu menghemat waktu dalam mengajar, mengubah peran pendidik menjadi fasilitator, meningkatkan proses pembelajaran menjadi lebih efektif dan interaktif, pedoman dalam proses pembelajaran dan alat evaluasi pembelajaran. Manfaat sumber belajar bagi peserta didik yaitu dapat digunakan untuk belajar secara mandiri, dapat belajar dimana saja dan kapan saja, dapat belajar sesuai dengan kecepatan masing-masing dalam memahami materi, dapat belajar dengan pilihan urutannya sendiri, membantu untuk menjadi mandiri, dan pedoman dalam proses pembelajaran (Prastowo, 2018). Sumber belajar berperan penting dalam kegiatan pembelajaran. Beberapa manfaat sumber belajar yaitu sebagai penunjang kegiatan pembelajaran, menambah dan memperluas sajian materi yang mungkin tidak terangkum didalam buku paket. Tersedianya sumber belajar juga diharapkan dapat mengatasi pemasalahan luasnya cakupan pokok bahasan dan kurangnya waktu pembelajaran disekolah.

Salah satu bentuk sumber belajar materi Animalia pada kelas Insekta ordo Lepidoptera yang dapat digunakan oleh siswa yaitu berupa media cetak. Media cetak merupakan sekumpulan bahan-bahan yang dicetak pada lembaran kertas dan digunakan untuk memperoleh informasi dan pengetahuan. Contoh media cetak diantaranya adalah buku teks, booklet, brosur, koran, dan majalah (Pribadi, 2017). Media cetak pada saat ini masih potensial digunakan walaupun perkembangan teknologi digital berkembang pesat. Penggunaan media cetak dalam pembelajaran memiliki keunggulan yaitu memiliki fleksibelitas yang tinggi. Fleksibelitas Media cetak diantaranya adalah dapat digunakan dimana saja dan kapan saja. Media cetak juga memiliki wujud dan jenis cetakan yang beragam, serta dapat diintegrasikan dengan media lainnya (Warsita, 2008). 
Berdasarkan hasil wawancara dan angket analisis kebutuhan didapatkan hasil bahwa sebagian besar sumber belajar yang digunakan siswa saat ini masih dalam bentuk buku yang kurang menarik. Buku yang tersedia juga tidak menjelaskan contoh-contoh hewan yang dapat ditemui disekitar (kontekstual). Selain itu, sulitnya mendapatkan buku materi animalia yang sesuai dengan tujuan pembelajaran menjadi kendala yang menyebabkan tidak tersedianya buku materi animalia di sekolah. Sehingga, diperlukan suatu inovasi baru untuk mengembangkan suatu sumber belajar yang sesuai dengan tujuan pembelajaran, berisi materi yang kontekstual, memiliki desain yang menarik serta disertai dengan gambar yang dapat memudahkan siswa dalam memahami materi animalia.

Salah satu cara membantu mengatasi masalah yang dialami siswa saat ini pada materi Animalia adalah dengan penggunaan booklet. Menurut French (2013) booklet adalah buku kecil yang terdiri dari 32 sampai 96 halaman dan maksimum berjumlah 100 halaman dengan 4 halaman sampul. Pendapat lainnya menyebutkan bahwa booklet berisi kurang dari 40.000 kata. Booklet memiliki cakupan bahasan yang terbatas, penyampaiannya sederhana dan hanya berfokus pada satu tujuan (French, 2013). Struktur booklet menyerupai buku yaitu terdiri dari pendahuluan, isi dan penutup namun penyajiannya jauh lebih singkat dari sebuah buku (Simamora, 2009). Pesan-pesan yang disampaikan dalam booklet ringkas dan disertai dengan gambar yang menarik (Muhammad, dkk. 2018). Selain itu, ukuran booklet yang lebih kecil dari buku membuat booklet sangat praktis untuk digunakan. Informasi dan pengetahuan dalam booklet umumnya dibahas secara ringan dan memudahkan pemahaman (Pribadi, 2017).

Keunggulan booklet yaitu informasi yang terdapat didalam booklet singkat, jelas serta dilengkapi dengan gambar, ukuran booklet yang kecil menyebabkan booklet mudah dibawa sehingga dapat dipelajari dimanapun (Hanzen, dkk., 2016), booklet mengandung teks, gambar dan foto yang dapat memudahkan pemahaman pembaca terhadap informasi yang disampaikan, tidak monoton, adanya teks, gambar dan foto menimbulkan minat untuk membacanya (Pane, dkk., 2020). Menurut Atiko (2019) manfaat booklet untuk siswa adalah membentuk keyakinan dan persepsi positif terhadap catatan yang diberikan guru, siswa bisa membaca booklet bersama teman-temannya dan saling berduskusi jika ada materi yang belum dipahaminya, bahasa yang sederhana dan dilengkapi dengan gambar menarik minat dan memudahkan pemahaman siswa. Sedangkan kelemahan booklet diantaranya adalah pembaca dituntut mempunyai kemampuan membaca yang baik (Pane, dkk., 2020).

Booklet mempunyai bentuk yang sederhana dengan deskripsi yang tidak terlalu panjang, menggunakan ilustrasi yang beragam dan penggunaan warna yang menarik serta diharapkan mampu meningkatkan minat dan memudahkan pemahaman siswa. Booklet yang dirancang sesuai dengan tujuan pembelajaran dan memuat jenis hewan yang berada di sekitar siswa diharapkan mampu memberikan

\section{Dewi, dkk}


pengalaman belajar yang nyata. Pemilihan booklet sebagai sumber belajar materi animalia juga didasarkan pada beberapa penelitian yang telah dilakukan diantaranya penelitian oleh Puspita et al. (2017) dan Mahendrani \& Sudarmin (2015) yang mendapatkan hasil bahwa booklet efektif digunakan dalam pembelajaran.

Kabupaten Kerinci merupakan Kabupaten di Provinsi Jambi yang memiliki kawasan hijau yang luas. Terdapat Taman Nasional Kerinci Seblat dan beberapa hutan adat yang merupakan habitat bagi berbagai jenis hewan dan tumbuhan. Beragamnya jenis hewan dan tumbuhan yang ada di Kabupaten Kerinci merupakan potensi yang bisa dimanfaatkan untuk mendukung pembelajaran. Berdasarkan observasi, salah satu jenis hewan yang ditemukan melimpah di Kabupaten Kerinci dan sekitarnya adalah anggota kelompok serangga yaitu Kupu-kupu.

\section{METODE PENELITIAN}

Model pengembangan yang digunakan dalam penelitian ini adalah model ADDIE. Model ADDIE terdiri dari 5 tahapan yaitu Analysis, Design, Development, Implementation dan Evaluation.

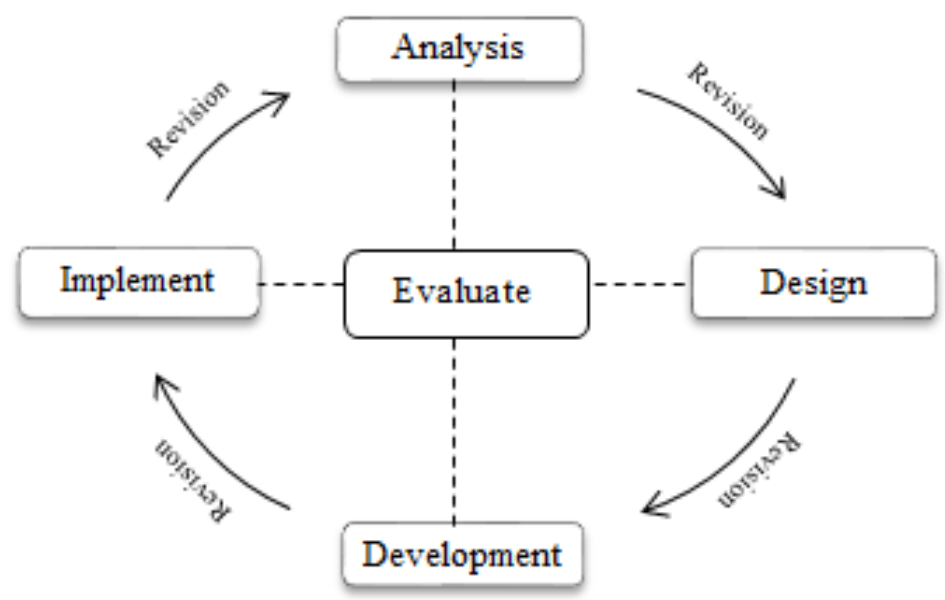

Gambar 1. Model pengembangan ADDIE (Branch, 2009)

1. Tahap Analisis

Tahap analis merupakan langkah awal yang dilakukan untuk mengumpulkan informasi yang berhubungan dengan proses pembelajaran di sekolah. Tahap analisis bertujuan untuk mengidentifikasi penyebab permasalahan yang terjadi dalam pembelajaran. Tahap analisis terdiri dari analisis kebutuhan dan identifikasi masalah berdasarkan hasil analisis kebutuhan. Tahap analisis 
dilakukan dengan menggunakan angket kebutuhan siswa, analisis silabus dan RPP, analisis karakterisitik siswa, observasi lapangan dan wawancara dengan guru mata pelajaran Biologi yang mengajar di kelas $X$. Langkah selanjutnya adalah mengidentifikasi masalah berdasarkan hasil analisis kebutuhan.

2. Tahap Desain

Tahap desain terdiri dari penentuan tim pengembang, menyiapkan sumber daya yang diperlukan, menyusun jadwal pengembangan, menentukan cakupan dan struktur materi, pembuatan story board, menentukan spesifikasi booklet dan membuat prototipe produk. Tim pengembang booklet keanekaragaman kupu-kupu di Kabupaten Kerinci dan sekitarnya terdiri dari peneliti sebagai pengembang utama produk, ahli media dan ahli materi sebagai penilai dan pemberi saran pada produk.

\section{Tahap Pengembangan}

Pada tahap pengembangan dilakukan penilaian atau validasi terhadap booklet keanekaragaman kupu-kupu di Kabupaten Kerinci dan sekitarnya. Selanjutnya dilakukan ujicoba produk pada guru biologi kelas X ( 2 orang) dan kelompok kecil (9 siswa). Validasi dilakukan dengan menggunakan angket validasi materi dan angket validasi media yang menggunakan skala linkert dengan 5 kriteria. Angket validasi materi dan angket validasi media masingmasing terdiri dari 20 pernyataan. Angket validasi media memuat pernyataanpernyataan aspek ukuran, aspek desain sampul dan desain isi booklet. Adapun instrument lembar angket validasi media menggunakan kisi-kisi yang dapat dilihat pada tabel 1 .

Tabel 1. Kisi-kisi instrumen validasi ahli media

\begin{tabular}{ll}
\hline \multicolumn{1}{c}{ Aspek } & \multicolumn{1}{c}{ Indikator } \\
\hline Ukuran booklet & Ukuran fisik booklet \\
\hline \multirow{2}{*}{ Desain sampul booklet } & Tipografi sampul booklet \\
& Tata letak sampul booklet \\
& Klustrasi sampul booklet \\
\hline & Konsistensi tata letak isi booklet \\
& Tata letak isi booklet \\
& Tata letak mempercepat pemahaman \\
& Tipografi isi booklet mudah dibaca \\
Desain isi booklet & Gambar dan ilustrasi booklet memperjelas dan memudahkan \\
& pemahaman \\
& llustrasi dan isi menimbulkan daya tarik \\
\hline
\end{tabular}


Adapun instrument lembar angket validasi media menggunakan kisi-kisi yang dapat dilihat pada tabel 2 . Angket validasi materi memuat pernyataanpernyataan aspek pengetahuan, isi dan bahasa. Validasi booklet dilakukan secara berkelanjutan sampai booklet keanekaragaman kupu-kupu di Kabupaten Kerinci dan sekitarnya dinyatakan layak untuk digunakan oleh ahli materi dan ahli media.

Tabel 2. Kisi-kisi instrumen validasi ahli materi

\begin{tabular}{ll}
\hline \multicolumn{1}{c}{ Aspek } & \multicolumn{1}{c}{ Indikator } \\
\hline Pengetahuan & Cakupan materi booklet \\
& Keakuratan materi booklet \\
& Kemutakhiran dan kontekstual materi \\
\hline Isi & Teknik penyajian booklet \\
& Pendukung penyajian materi \\
& Kelengkapan penyajian booklet \\
\hline Kebahasaan & Kesesuaian dengan perkembangan peserta didik \\
& Kelugasan \\
& Penggunaan istilah \\
\hline
\end{tabular}

4. Tahap Implementasi

Tahap keempat adalah implementasi sumber belajar yang dilakukan di salah satu SMA di Kerinci. Pada tahap implementasi dilakukan ujicoba kelompok besar pada 30 orang siswa.

5. Tahap Evaluasi

Pada tahap evaluasi dilakukan evaluasi secara keseluruhan terhadap tahaptahap model ADDIE yang telah dilakukan dalam pengembangan booklet keanekaragaman kupu-kupu di Kabupaten Kerinci dan sekitarnya. 


\section{HASIL DAN PEMBAHASAN}

Ahli media berperan dalam memberi saran dan kritik terhadap media yang bertujuan untuk mengetahui kualitas media yang telah dikembangkan (Suryani dkk., 2018). Kelayakan produk dinilai oleh dua ahli yaitu ahli media dan ahli materi. Validasi media dan materi dilakukan dalam tiga tahap. Berikut adalah grafik proses tahapan validasi ahli media dapat dilihat pada Gambar 3.

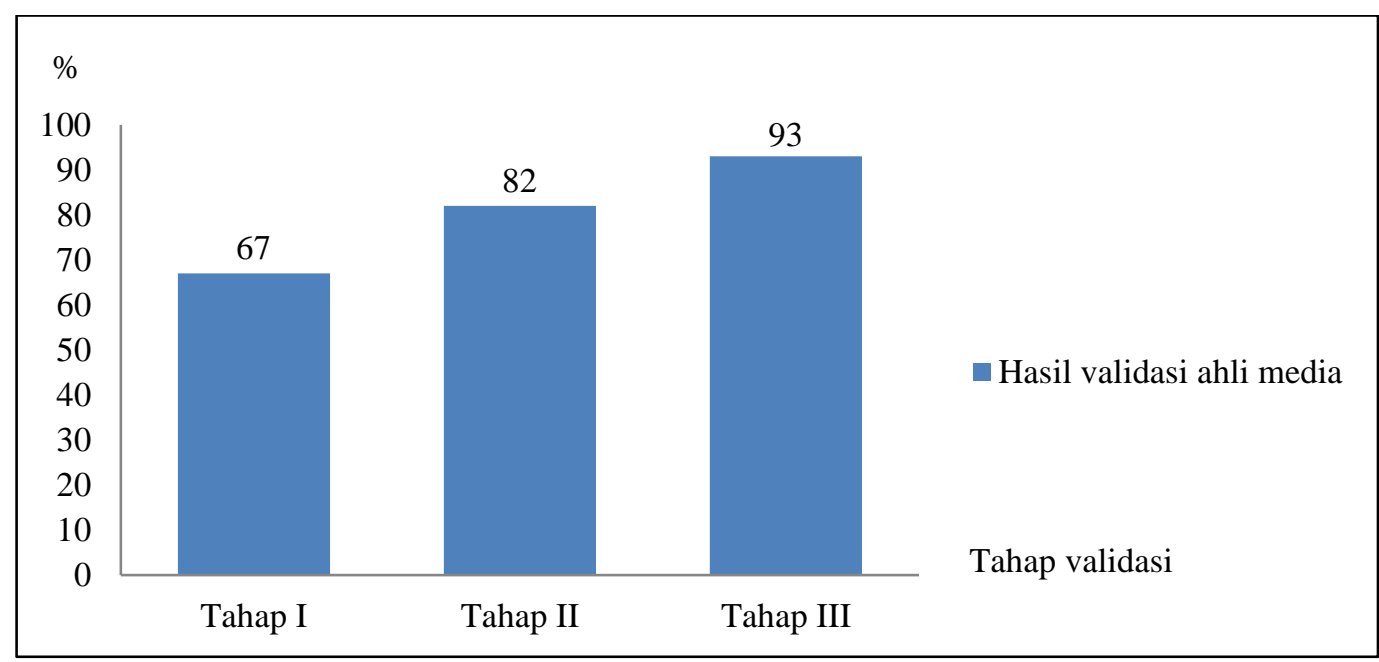

Gambar 2. Proses tahapan validasi ahli media

Grafik proses tahapan validasi ahli materi dapat dilihat pada Gambar 4.

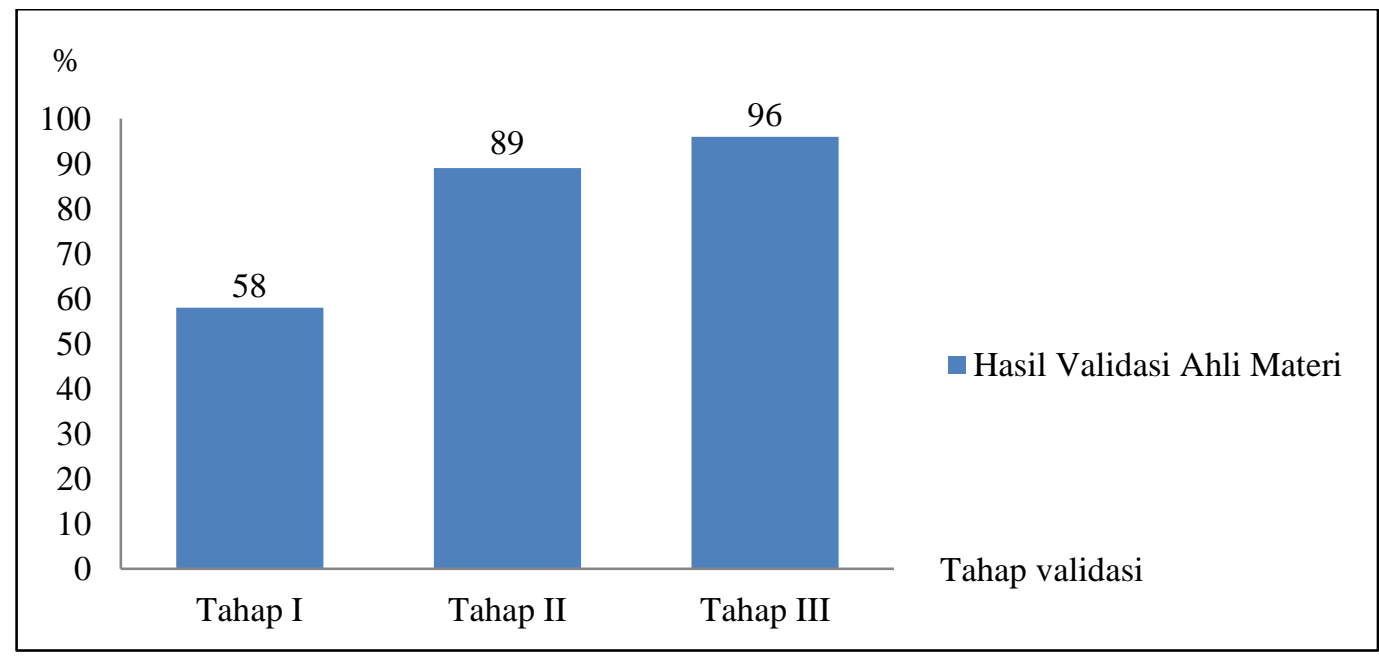

Gambar 3. Proses tahapan validasi ahli materi 
Hasil akhir validasi ahli media dan ahli materi dapat dilihat pada Tabel 3 .

Tabel 3. Hasil akhir validasi ahli media dan ahli materi

\begin{tabular}{llcc}
\hline No. & \multicolumn{1}{c}{ Ahli } & Persentase (\%) & Kriteria \\
\hline 1. & Media & 93 & Sangat Layak \\
& - Ukuran booklet & & \\
& - Desain sampul booklet & & \\
& - Desain isi booklet & & \\
2. & Materi & 96 & \\
& - Pengetahuan & & \\
& - Isi & & \\
& - Kebahasaan & & \\
\hline
\end{tabular}

Selain memberikan penilaian dalam bentuk angka, validator juga memberikan penilaian dalam bentuk saran-saran untuk dapat dijadikan sebagai dasar dilakukannya revisi terhadap sumber belajar yang dikembangkan. Saran-saran tesebut disajikan dalam Tabel 4.

Tabel 4. Saran-Saran Perbaikan oleh Validator

\begin{tabular}{ll}
\hline Validator & \multicolumn{1}{c}{ Saran yang Dikemukakan } \\
\hline Ahli media & 1. Ukuran booklet belum memenuhi ukuran standar. Ukuran lebar \\
booklet masih kurang.
\end{tabular}

Berikut merupakan revisi yang telah dilakukan pada booklet keanekaragaman kupu-kupu di Kabupaten Kerinci dan sekitarnya berdasarkan saran dari validator media. 
Tabel 5. Tampilan media sebelum dan sesudah validasi

\begin{tabular}{|c|c|c|c|}
\hline No. & \multicolumn{1}{|c|}{ Tampilan media sebelum validasi } & \multicolumn{1}{c|}{ Tampilan media setelah validasi } \\
\hline 1. & $\begin{array}{l}\text { Sampul belum menggambarkan lokasi } \\
\text { pengkoleksian kupu-kupu (Kabupaten } \\
\text { Kerinci). } \\
\begin{array}{l}\text { Ukuran judul booklet kecil sehingga tidak } \\
\text { proposional dan tidak menjadi pusat pandang. }\end{array}\end{array}$ & $\begin{array}{l}\text { Sampul sudah mengambarkan lokasi } \\
\text { pengkoleksian kupu-kupu (Kabupaten } \\
\text { Kerinci). } \\
\text { Ukuran judul booklet diperbesar. }\end{array}$ \\
\hline 2. & &
\end{tabular}




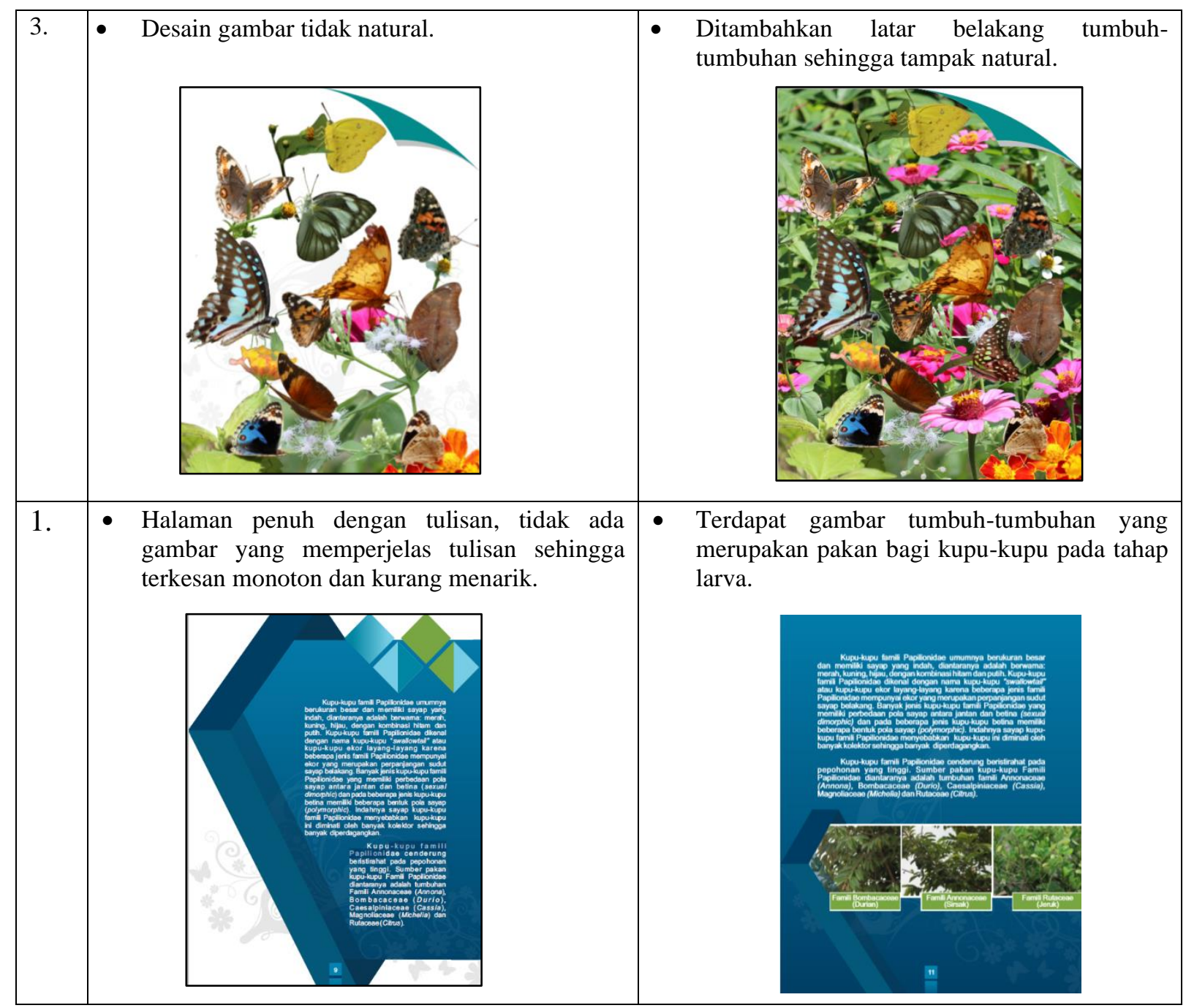




\begin{tabular}{|l|l|l|l|l|}
\hline 5. & $\begin{array}{l}\text { Gambar sayap kurang jelas sehingga tidak } \\
\text { tampak karakterisitik sayap kupu-kupu jantan } \\
\text { dan betina. }\end{array}$ & $\begin{array}{l}\text { Gambar diganti sehingga tampak } \\
\text { karakterisitik sayap kupu-kupu jantan dan } \\
\text { betina. }\end{array}$ \\
\hline 6. & Ukuran judul tidak proporsional. \\
\hline
\end{tabular}




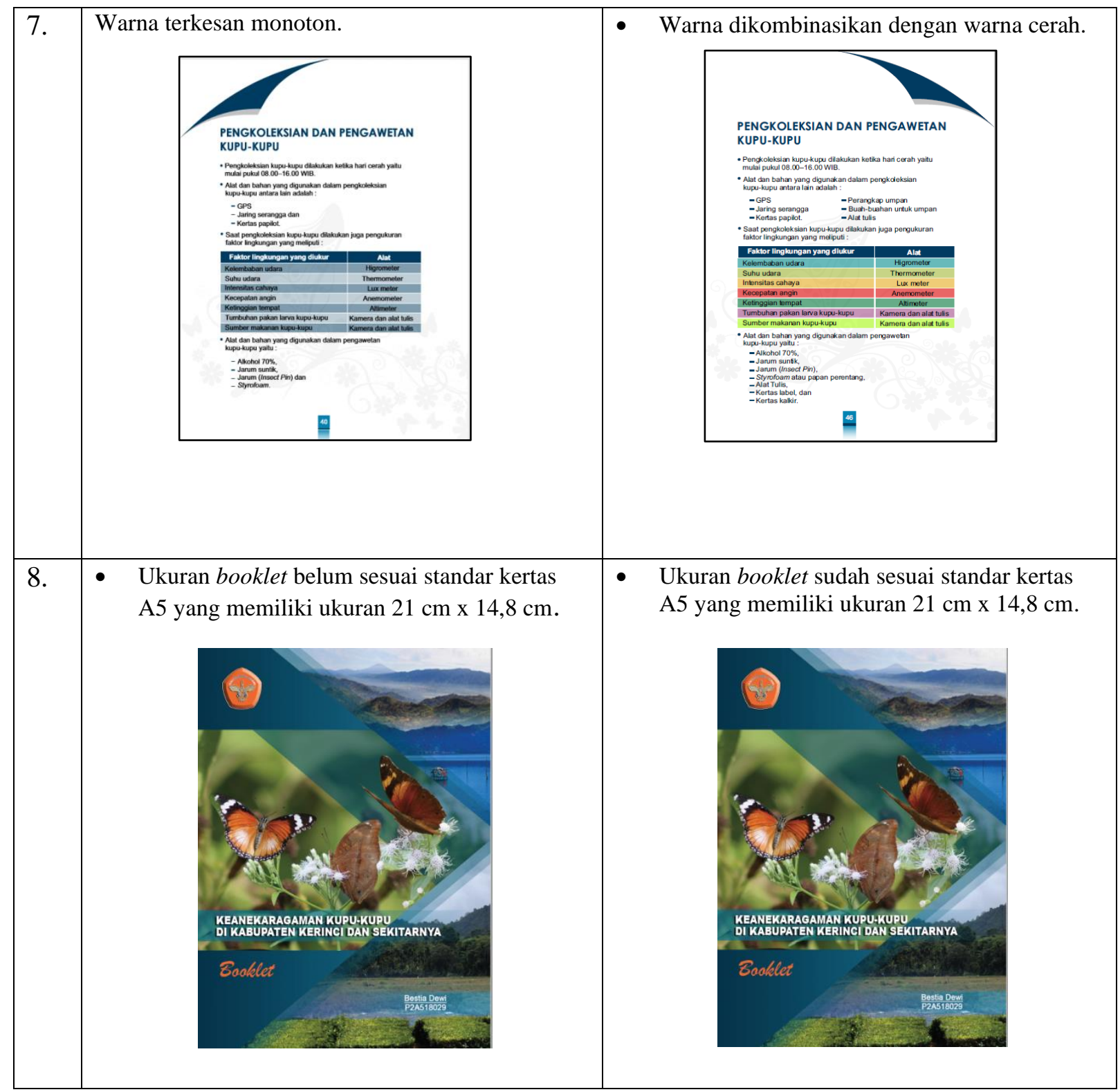

Setelah booklet keanekaragaman kupu-kupu di Kabupaten Kerinci dan sekitarnya direvisi sesuai saran validator media dan materi, booklet diujicobakan pada guru dan siswa.. Hasil analisis data respon siswa pada ujicoba kelompok kecil dapat dilihat pada Tabel 6 .

Tabel 6. Hasil analisis data respon siswa kelompok kecil

\begin{tabular}{clccl}
\hline No & Aspek & Jumlah skor & Persentase $(\%)$ & \multicolumn{1}{c}{ Kategori } \\
\hline 1. & Materi & 74 & 82,22 & Baik \\
2. & Sajian & 121 & 82,22 & Baik \\
3. & Bahasa & 39 & 86,66 & Sangat Baik \\
4. & Kebermanfaatan & 147 & 81,66 & Baik \\
\hline & Total & 381 & 84,66 & Sangat Baik \\
\hline
\end{tabular}


Hasil analisis data respon siswa pada ujicoba kelompok kecil yang meliputi aspek materi, sajian, Bahasa, dan kebermanfaatan dapat dilihat pada Tabel 7.

Tabel 7. Hasil analisis data respon siswa kelompok besar

\begin{tabular}{clccl}
\hline No & Aspek & Jumlah skor & Persentase (\%) & \multicolumn{1}{c}{ Kategori } \\
\hline 1. & Materi & 267 & 89 & Sangat baik \\
2. & Sajian & 408 & 90,66 & Sangat baik \\
3. & Bahasa & 119 & 79,33 & Baik \\
4. & Kebermanfaatan & 502 & 83,66 & Baik \\
\hline \multicolumn{2}{r}{ Total } & 1296 & 86,40 & Sangat baik \\
\hline
\end{tabular}

Untuk melihat gambaran kesepakatan yang diberikan oleh siswa terhadap booklet keanekaragaman kupu-kupu di Kabupaten Kerinci dan sekitarnya dilakukan uji Kappa. Uji Kappa dilakukan dengan menggunakan software Statistical Package for the Social Sciences (SPSS). Hasil uji Kappa dapat dilihat pada Tabel 8.

Tabel 8. Hasil uji Kappa

\begin{tabular}{lrrrrr}
\hline \multicolumn{5}{c}{ Symmetric Measures } & \\
\hline & Value & $\begin{array}{c}\text { Asymptotic } \\
\text { Standard Error }\end{array}$ & Approximate Tb & $\begin{array}{c}\text { Approximate } \\
\text { Significance }\end{array}$ \\
\hline Measure of Agreement Kappa & .769 & .113 & 8.159 & .000 \\
\hline N of Valid Cases & 15 & & & \\
\hline
\end{tabular}

Berdasarkan Tabel 8 diperoleh koefisien cohen's Kappa sebesar 0,769 dengan nilai signifikan sebesar 0.000 . Nilai signifikan yang didapatkan $<0,05$ maka Ha diterima yang berarti terdapat kesepakatan yang sangat baik antara kelompok siswa 1 dengan kelompok siswa 2 terhadap booklet keanekaragaman kupu-kupu di Kabupaten Kerinci dan sekitarnya. Hasil analisis data respon guru yang dilakukan oleh dua orang guru mata pelajaran Biologi dapat dilihat pada Tabel 9.

Tabel 9. Hasil analisis data respon guru

\begin{tabular}{clccc}
\hline No & Aspek & Jumlah skor & Persentase (\%) & Kategori \\
\hline 1. & Isi & 25 & 83,33 & Baik \\
2. & Penyajian & 25 & 83,33 & Baik \\
3. & Bahasa & 8 & 80 & Baik \\
4. & kebermanfaatan & 25 & 83,33 & Baik \\
\hline \multicolumn{2}{r}{ Total } & 83 & 83 & Baik \\
\hline
\end{tabular}

\section{Dewi, dkk}




\section{KESIMPULAN}

Booklet keanekaragaman kupu-kupu di Kabupaten Kerinci dan sekitarnya telah berhasil kembangkan dan telah melewati tahap validasi dari para ahli materi dan ahli media. . Booklet keanekaragaman kupu-kupu di Kabupaten Kerinci dan sekitarnya divalidasi oleh ahli media dan ahli materi dengan hasil sangat layak. Hasil respon guru memperoleh persentase $83 \%$ dengan kategori baik, ujicoba kelompok kecil memperoleh persentase $84,66 \%$ dengan kategori sangat baik dan ujicoba kelompok besar memperoleh persentase $86,4 \%$ dengan kategori sangat baik. Hasil evaluasi menunjukkan bahwa booklet keanekaragaman kupu-kupu di Kabupaten Kerinci dan sekitarnya dapat digunakan sebagai sumber belajar materi Animalia kelas X SMA.

\section{DAFTAR PUSTAKA}

Atiko. (2019). Booklet, Brosur dan Poster Sebagai Karya Inovatif di Kelas. Surabaya: Caremedia Communication.

Branch. R.M. (2009). Instructional Design: The ADDIE Approach. New York : Springer.

Daryanto. (2016). Media Pembelajaran Peranannya Sangat Penting dalam Mencapai Tujuan Pembelajaran Edisi ke-2 Revisi. Jogjakarta: Gava Media.

French, C. (2013). How to Write a Successful How-to Booklet. The Endless Bookcase.

Hanzen, W. F. E., Hastuti, U. S., \& Lukiati, B. (2016). Pengembangan Booklet Pembuatan Yoghurt Kulit Buah Naga Untuk Para Petani Buah Berbasis Pada Hasil Penelitian. Jurnal Pendidikan, 1(11), 2140-2144.

Mahendrani, K., \& Sudarmin. (2015). Pengembangan Booklet Etnosains Fotografi Tema Ekosistem untuk Meningkatkan Hasil Belajar pada Siswa SMP. USEJ Unnes Science Education Journal, 4(2), 865-872. https://doi.org/10.15294/usej.v4i2.7936

Muhammad, F., Muhiddin, P., \& Adnan. (2018). Pembelajaran Arthropoda Menggunakan Booklet Sebagai Sumber Belajar Mandiri Siswa Kelas X SMA / MA Biology Teaching and Learning. Jurnal Biology Teaching and Learning, 1(1), 28-32.

Pane, N., Napitupulu, D., \& Nurfathiyah, P. (2020). Pengaruh Foto dan Lukisan pada Buklet Terhadap Peningkatan Pengetahuan Petani Padi Sawah Tentang Pupuk Organik di Desa Lagan Ulu. Sosio Ekonomika Bisnis, ISSN 1412-, 4047. https://www.neliti.com/publications/43684/pengaruh-foto-dan-lukisan-padabuklet-terhadap-peningkatan-pengetahuan-petani-pa

Pribadi, B. A. (2017). Media dan Teknologi dalam Pembelajaran. Jakarta: 
Prenadamedia Group.

Prastowo, A. (2018). Sumber Belajar dan Pusat Sumber Belajar. Jakarta: Prenadamedia Group.

Puspita, A., Kurniawan, A. D., \& Rahayu, H. M. (2017). Pengembangan Media Pembelajaran Booklet pada Materi Sistem Imun Terhadap Hasil Belajar Siswa Kelas XI SMAN 8 Pontianak. Jurnal Bioeducation, 4(1), 64-73. https://doi.org/10.29406/524

Simamora, R. H. (2009). roymond simamora. Penerbit Buku kedokteran EGC.

Suryani, N., Setiawan, A., \& Putria, A. (2018). Media Pembelajaran Inovatif dan Pengembangannya. PT. Remaja Rosdakarya.

Warsita, B. (2008). Teknologi pembelajaran landasan dan aplikasinya. Jakarta: Rineka Cipta. 